\title{
Processos de criação em dublagem
}

\section{Robson Kumode Wodevotzky}

Doutorando e mestre em Comunicação e Semiótica pela PUC-SP, e bacharel em Rádio e TV pela Universidade Anhembi Morumbi. É ator, dublador e diretor de dublagem.

E-mail: robsonkumode@gmail.com

\section{Norval Baitello Jr.}

Docente titular na Pós-graduação em Comunicação e Semiótica da PUC-SP. Foi professor convidado das Universidades de Viena, Sevilha, S. Petersburg, Autónoma de Barcelona e Évora. Livros mais recentes: La era de la Iconofagia, Flussers völlerei e $O$ pensamento sentado: Sobre glúteos cadeiras e imagens. De 2007 a 2016 foi coordenador da área de Comunicação e Ciência da Informação da Fapesp.

E-mail: norvalbaitello@pucsp.br
Resumo: Dublagem é a substituição de diálogos da faixa sonora original pela voz de atores (dubladores) em outro idioma, que pretendem sincronizar o novo som na imagem pré-existente sem que haja alteração na construção de sentido da obra. $O$ presente artigo procura cartografar os elementos constitutivos dos processos de criação do dublador e introduzir uma reflexão sobre a dinâmica de repetição do intérprete, em seus aspectos formais e imaginativos, sob a luz dos processos de preparação do ator de Constantin Stanislavski, da teoria da imagem de Norval Baitello Jr. e do conceito de repetição trabalhado por Sören Kierkegaard.

Palavras-chave: Dublagem; Processos de criação; Repetição; Iconofagia; Imagem sonora.

\section{Dubbing creative processes}

Abstract: Dubbing is the replacement of dialogues in an audiovisual original soundtrack by the voice of actors (dubbers) in another language, who wants to synchronize the new sound in the pre-existing image without changing the meaning construction of the original product. This article seeks to map the constituent elements of the voice actor's processes of creation and to introduce a reflection on the performance's repetition, in its formal and imaginative aspects, in the light of Constantin Stanislavski's actor preparation processes, Norval Baitello Jr.'s theory of image, and the concept of repetition worked by Sören Kierkegaard.

Keywords: Dubbing; Creative processes; Repetition; Iconophagy; Sound image. 


\section{Introdução}

É importante estabelecer, de início, o recorte conceitual sobre dublagem que se pretende abordar no presente artigo. Compreender-se-á dublagem como a substituição da faixa sonora de diálogos originais por diálogos em outro idioma (num processo de tradução), que utiliza-se do lipsync - a sincronização labial feita pelo dublador, ator de voz especialista nesse processo que, buscando a maior transparência possível, tentará simular que sua voz é a voz do ator que se vê na imagem. Assim, excluem-se como dublagem os processos já conhecidos embora frequentemente confundidos como dublagem - de ADR (Additional dialogue recording: quando há substituição ou adição de diálogos no mesmo idioma para que se melhore ou se reconstrua o som captado diretamente na cena), de localização de games (substituição de diálogos originais por outra língua feita especificamente para games, que possui outra práxis), e de criação de voz original (quando atores criam vozes para personagens em produções originais, ou seja, não pretendem substituir uma faixa sonora já existente, e na maioria dos casos o áudio gravado é base para a criação da imagem visual e não o contrário).

A dublagem possui um papel fundamental na infiltração de produtos audiovisuais estrangeiros. Seja pelo discurso da inclusão, da facilitação do consumo de acordo com as práticas de recepção, ou do aumento da monetização desses audiovisuais, o objetivo é que se encontre mais capilaridade, alcançando maior audiência e distribuição do produto. A dublagem contribui para o acesso de analfabetos, analfabetos funcionais e deficientes visuais que não conseguem acompanhar as legendas, que traduzem textualmente na tela os diálogos originais do produto audiovisual para o idioma do local a ser consumido. Também ajuda em contextos onde se dificulta a leitura de legendas, como telas miniaturizadas - prática cada vez mais comum no consumo audiovisual -, ou ambientes onde a escuta prevalece, seja com a concorrência de múltiplas telas no consumo - de tablets, celulares, notebooks, enquanto assiste-se o filme na televisão, por exemplo -, ou até mesmo pela cultura radiofônica enraizada no consumo televisivo, que permite o deslocar-se pelo espaço enquanto acompanha-se sonoramente o conteúdo, considerando a concorrência de outros elementos presentes nos ambientes. Ademais, a dublagem facilita a contemplação visual ao poupar ao espectador a leitura da legenda, mais uma informação dentre os inúmeros elementos já existentes na obra - entre áudio e imagem. Por outro lado, pode-se destacar apenas o objetivo de maior monetização desses produtos: com um alcance maior de espectadores lucra-se mais, impõe-se mais o produto e todo o imaginário - cultural, ideologizante imbuído (direta ou indiretamente) no audiovisual difundido.

Assim, como o propósito não é criar um novo produto, mas fortalecer a distribuição de uma obra já existente, cabe à dublagem ser o mais fiel possível à obra original, apresentando-se como uma tradução intersemiótica dos diálogos originais, agora em novo idioma. A opção pelo conceito de tradução intersemiótica deu-se pelo fato de não se tratar apenas da tradução do código linguístico, mas de um complexo sistema de signos - microgestuais, de múltiplas camadas interpretativas (que serão abordadas a seguir) - que contaminam ou determinam a construção de sentido e comparecem no áudio dublado. Destarte, pretende-se que o regime de sentidos da obra não seja modificado.

${ }^{1}$ Em Portugal, o processo de dublagem é conhecido como dobragem, no sentido de duplicação.
Para tanto, a dublagem se constrói em um processo reprodutivo, no qual o dublador deve apropriar-se de (e duplicar ${ }^{1}$ ) alguns elementos presentes no audiovisual original a fim de sincronizar sua voz no corpo de outrem, sendo fiel à interpretação do ator presente na tela, cuja imagem é referência e plataforma para o desenvolvimento de seu trabalho. Parte, portanto, de uma relação estético-formal que norteia e apoia todo o desenvolvimento posterior. Contudo, 
2 Como exemplo de possíveis desdobramentos temáticos que a tradução linguística pode abordar e que interfere na formalidade da composição da dublagem, estão os formatos de boca. Em busca de uma maior transparência no resultado estético final, a tradução pode procurar por palavras - sem modificar ou perder o sentido do contexto original que encaixem melhor no movimento bucolabial que a imagem na tela apresenta. Assim, pode-se levantar duas características: 1) a cadência rítmica (número de batidas - abrir e fechar da boca) com relação ao número de sílabas e a velocidade em que serão faladas; 2 ) os movimentos bucolinguais fortes, quando visivelmente mais destacados [ex: bilabiais - quando o lábio toca o lábio com pressão nos sons de $/ b /, / p /$, e $/ m /$; labiodentais - quando o lábio toca nos dentes como nos sons de /f/ e / $/ \mathrm{V}$; lingopalatais - quando a língua bate no palato, como nos sons de $/ g /$ e $/ q /$; lingodentais - batida de língua com dentes, como nos sons de $/ \mathrm{l} / \mathrm{l} / \mathrm{d} / \mathrm{e} / \mathrm{t} /$; vogais abertas, com a boca mais aberta, como $/ a /$ e $/ e /$; vogais fechadas, com a boca mais fechada, como /u/ e /o/; etc. (ZARATIN, 2010: 26)], procurando uma tradução onde as palavras quando faladas no idioma dublado coincidam, dentro da cadência rítmica, com os mesmos movimentos fortes encontrados no idioma original. como será demonstrado a seguir, o processo de construção utiliza-se de imagens que se apresentam na tela, mas deve procurar não apagar a subjetividade e a relação do artista (dublador) frente a elas, buscando um processo de repetição (no sentido de KIERKEGAARD, 2009) da interpretação original.

Neste artigo, o recorte é o processo de criação do dublador frente às imagens que se apresentam e se relacionam com ele, e tentar-se-á mapear e introduzir um pensamento sobre os aspectos formais e imaginativos implicados; não faz parte do objetivo discutir ou abordar a questão da tradução linguística, parte do processo e que se desdobra em inúmeras outras questões que não cabem ao presente trabalho ${ }^{2}$.

\section{A imagem sonora na dublagem: entre forma e imaginação}

Diferentemente do processo de criação de personagens que se utilizam de textos/roteiros - no qual o ator, a partir de circunstâncias dadas (presentes no texto de forma lacunar: a linearidade da escrita e a limitação do código linguístico não é capaz de transmitir toda a complexidade da ação física), apoia-se para o desenvolvimento de suas imagens endógenas, para que então culminem em suas ações corpóreas -, o dublador inicia sua atividade na observação minuciosa de uma obra audiovisual finalizada, com todas as ações e elementos presentes, na qual se apoiará para o processo de repetição.

Constantin Stanislavski, teórico teatral que desenvolveu um longo estudo sobre os processos de preparação do ator e construção de personagens, define as circunstâncias dadas como informações presentes no texto teatral fornecidas pelo autor da obra e que determinam parte do processo de criação do ator, que não pode se desprender dessas informações em seu trabalho criativo (STANISLAVSKI, 1996: 68-79). Contudo, deixa também explícito, no diálogo entre o Diretor e Gricha na obra A Preparação do Ator, que as circunstâncias dadas precisam ser completadas com a imaginação do ator:

- Mas - interrompeu Gricha - o que é que sobra para o ator, já que tudo é preparado pelos outros? Só ninharias?

- O que é que está dizendo... ninharias? - replicou o Diretor, indignado. Acha que acreditar na ficção imaginativa de outra pessoa e trazê-la à vida é ninharia? Não sabe que é muito mais difícil trazer uma composição sobre um tema sugerido por terceiros do que inventá-la nós mesmos? [...] Filtramos, através de nós, todo o material que recebemos do autor e do Diretor. Elaboramos esse material, completando-o com a nossa própria imaginação. Ele passa a ser parte de nós, espiritual e até fisicamente. (STANISLAVSKI, 1996: 79)

Para a dublagem, as circunstâncias dadas são a própria obra audiovisual, que já está completamente finalizada. É possível conferir nas cenas os personagens, os ambientes, os gestos, as intenções, a atmosfera, as ações etc. Imagens audiovisuais apresentam menos lacunas que imagens textuais: são capazes de transmitir elementos que serão absorvidos por duas sensorialidades (visão e audição), enquanto que textos são abstrações de imagens e/ou propostas de imagens e, assim sendo, apresentam lacunas que foram abstraídas da imagem que pretendem descrever ou que precisam ser preenchidas na imagem que podem construir. Vilém Flusser, comunicólogo que desenvolveu um vasto pensamento sobre imagens, em sua articulação sobre a escalada da abstração demonstra que imagens são abstrações de acontecimentos, enquanto que textos são abstrações de imagens, tentativas de explicação delas (FLUSSER, 2013: 102103); contudo, em seu estudo sobre os diferentes usos da escrita, ele também demonstra que textos, em formato de roteiros, podem apontar de volta às imagens e "assim a história, que há três mil anos brotou das imagens, corre, por 
${ }^{3}$ Cf. Vilém Flusser. O programa, embora programado por um programador, passa a programar o programador, que então age automatizado de acordo com os desejos do programa. Assim, pensa programar quando na verdade é programado. (FLUSSER, 2013: 64-65) meio dos vasos capilares dos roteiros, de volta para as imagens" (FLUSSER, 2010: 214).

Por possuírem menos lacunas e, portanto, exigirem menos da capacidade imaginativa de seu preenchimento na reconstrução da cena, deve-se ter cuidado para não deixar que as imagens audiovisuais se apresentem ditatorialmente no processo de criação em dublagem, obliterando a potência de composição da imagem sonora que utiliza-se também das imagens endógenas, da imaginação do dublador; passando a programar ${ }^{3}$, por seus aspectos formais, toda a execução do trabalho do intérprete, eliminando os processos subjetivos e limitando-o à imitação estética do material original que, destarte, desenvolverá um eco do produto original. $\mathrm{O}$ audiovisual original deve se apresentar como referência ao desenvolvimento das imagens endógenas do dublador e como delimitação formal de sua execução vocal: embora o produto final deva parecer-se com a referência original, não pode limitar-se em sua totalidade a ela, sob o risco de não soar verdadeiro, ser apenas uma carcaça estético-formal sem preenchimento; não obstante, não pode subverter ou perder o sentido conferido no original, tampouco escapar de seus processos formais.

Stanislavski já divide esse duplo movimento entre circunstâncias dadas (externas) e imaginação (interna), e se preocupa com o movimento interno no processo criativo do ator. Em uma passagem, sobre a ação de interpretar uma pessoa apaixonada, diz que

Se vocês executarem, em sua imaginação - tendo por base uma rigorosa observação das circunstâncias dadas, reflexões adequadas e sinceridade de sentimentos -, cada passo desta série de ações, descobrirão que, primeiro externa e depois internamente, chegarão ao estado de uma pessoa apaixonada. Com base nesses preparativos, vocês acharão mais fácil assumir um papel e uma peça em que figure essa paixão. (STANISLAVSKI, 1997b: 71)

Também constrói um pensamento sobre a imaginação, como na seguinte passagem em que Stanislavski deixa clara sua preocupação com a formação das imagens interiores.

As imagens interiores são formadas dentro de nós, em nossa imaginação, em nossas lembranças; em seguida, tais imagens são, por assim dizer, exteriorizadas, o que nos permite examiná-las. Entretanto, é como se olhássemos para estes objetos imaginários a partir do seu interior, com os nossos olhos interiores, e não com os exteriores. Em outras palavras, podemos dizer que, embora essas imagens e objetos imaginários nos sejam sugeridos pela vida exterior, sua configuração inicial dá-se dentro de nós, em nossa memória e imaginação. Apenas sob o pano de fundo de tais explicações é que podemos aceitar o termo "visão interior". (STANISLAVSKI, 1997b: 206)

A construção de uma imagem acontece em um duplo movimento: uma imagem exógena se apresenta em uma plataforma midiática (uma pintura em um papel, por exemplo, ou uma imagem audiovisual em movimento); uma pessoa frente a essa imagem exógena imagina-a de forma endógena; no encontro desses dois movimentos, no choque, se dá a imagem: a imagem exógena precisa ser animada por um corpo, enquanto que o corpo precisa de um suporte midiático para que as imagens possam ser fixadas e transportadas para além dele. A imagem, portanto, não está somente na plataforma midiática, tampouco apenas na imaginação de quem a concebe: está no duplo movimento criado entre ambas (BELTING, 2014: 43-44). E para que este movimento aconteça, é necessário que o corpo esteja ativo para ter força de imaginação. Caso contrário, as imagens exógenas impõem-se contra o corpo, usurpando o espaço endógeno de produção de imagens e colocando-se como se fossem as próprias imagens produzidas pelo 
4 Aqui, prosódia é o conjunto final da sonoridade da fala: musicalidade, tom, volume, intenção, intensidade e qualquer outro elemento que altere a sonoridade. corpo, em um movimento de esvaziamento, onde o turbilhão de imagens exógenas - em seus aspectos excessivamente estetizantes - esvazia a produção de sentidos (BAITELLO, 2014).

No desenvolvimento da dublagem é preciso que a emoção reproduzida pelo dublador seja verdadeiramente processada e imaginada (internamente), pois comparece na prosódia ${ }^{4}$ emitida; no entanto, alguns pontos não podem divergir do material original, pois corre-se o risco de perder a sincronia com a imagem, de não ser verossímil o efeito de que a voz está saindo da imagem do corpo do ator na tela. Assim, o trabalho de composição do dublador inicia-se pela referência das imagens no produto audiovisual, que servirão de insumo para a criação de suas imagens endógenas e preenchimento de seus sentimentos, e formalmente delimitarão parte da composição final. Esta composição final não é mera formalidade, mas síntese entre a forma e o movimento interno do dublador, entre a imagem visual que serviu de base e será a plataforma da composição final e as imagens endógenas repletas de emoções do artista: finaliza-se como uma imagem sonora, não apenas como sons em uma boca, mas síntese de um movimento ambiental endógeno-exógeno [imagem externa referente - emoção interna (imaginação) - forma sonora sincronizada à imagem externa]; um complexo sonoro, uma imagem sonora.

Stanislavski diz que olhar para a imagem a que se pretende chegar é um ato perigoso, pois "ensina o ator a observar antes o exterior que o interior da alma, tanto em si mesmo quanto no papel" (STANISLAVSKI, 1996: 48). Todavia, na dublagem o processo necessariamente inicia-se na observação da forma em que se deve chegar, para que então, posteriormente, se preencha a alma do personagem. Por isso, a observação e duplicação dos elementos que serão detalhados a seguir, de ordem mecânica, não podem ser encarados como a totalidade do trabalho, embora devam comparecer obrigatoriamente no resultado final. É interessante notar que Stanislavski já se preocupava com a influência das imagens exógenas sobre o processo de construção do ator, apontando para uma possível obliteração da construção da imagem interior do ator (imaginação) pela influência excessiva de imagens exteriores, sobretudo em seus aspectos estetizantes. Em uma passagem dedicada à fala, Stanislavski diz que

\footnotetext{
A fala é música. A pronúncia, em cena, é uma arte tão difícil como o canto. [...] Quando um ator acrescenta um intenso ornamento sonoro ao conteúdo vivo das palavras, posso entrever, através de uma visão interior, as imagens que foram configuradas por sua própria imaginação criadora. [...] Para o ator, uma palavra não é apenas um som, mas também a evocação de imagens. [...] 0 trabalho de vocês é insinuar, nos outros, as suas visões interiores, e expressálas em palavras. (STANISLAVSKI, 1997b: 89)
}

Isso posto, fica clara a preocupação de Stanislavski com o exercício da fala, sobretudo quanto ao uso de imagens internas na composição do som: a fala evoca imagens internas; o som da fala é a expressão das imagens endógenas, da força da imaginação do ator. Em outro momento, Stanislavski diz que a reprodução excessiva da fala pode levar ao seu esvaziamento

As falas, tão repetidas nos ensaios e em inúmeras representações, acabam sendo mecanicamente repetidas. O conteúdo interior do texto se esvai, e tudo o que resta é uma sonoridade mecânica. Preservem as suas falas por duas importantes razões: para que não sejam gastas pelo uso, e para que nenhum palavreado oco venha perturbar a configuração básica do subtexto. (STANISLAVSKI, 1997b: 90-91) 
5 O conceito de "excessivamente ou exclusivamente estetizante" está sendo usado aqui como ferramenta conceitual a partir de seu uso por Aby Warburg, relatado por seu discípulo Carl Georg Heise. Em seu livro, Recordações pessoais de Aby Warburg, relatando suas conversas com o mestre, Heise evoca o momento em que Warburg condena o "exclusivamente estetizante" como critério para o entendimento da História da Arte, pois tal olhar oblitera a genealogia de uma imagem, sua etimologia profunda, sua densidade histórica, fundamentos de sua capacidade de impactar. Warburg encaminhava tais obras "exclusivamente estetizantes" a um setor específico de sua biblioteca, o "guarda-venenos" (Giftschrank). Entendemos aqui que o "apenas estetizante" seria uma valorização excessiva das características formais em detrimento de uma percepção relacional dos ambientes a serem dublados. (HEISE, 2005: 15-16)

${ }^{6}$ Cf. Eibl-Eibesfeldt (1983) em seu estudo de etologia comparada, onde descreve a importância dos microgestos.
Eis o paradoxo do trabalho do dublador: por um lado repetir sem esvaziar, por outro preencher sem sair da forma exposta no material original. Por isso a importância da imaginação. A eliminação do processo de imaginação, de composição das imagens endógenas, e a excessiva preocupação com os elementos "excessivamente ou exclusivamente estetizantes" ${ }^{5}$ podem levar à mecanização das falas, criando sons ocos, esvaziados, apenas mecanicamente reproduzidos e que, além de não evocar as imagens endógenas do dublador, podem obliterar seu poder imaginativo.

\section{A forma da voz na dublagem}

É preciso ter cuidado com os pontos formais que serão levantados a seguir, pois eles não podem ser a totalidade do processo de execução do dublador, embora sejam imprescindíveis para que se dê o efeito de que a dublagem precisa.

Os elementos que devem ser duplicados, de maneira fiel e formal ao material original, são: volume, tom, intenção, intensidade da intenção e tempo-ritmo. Esses elementos, se não reproduzidos exatamente como aparecem no original, descolam a voz do dublador da imagem do ator no qual pretende se sincronizar - suspende-se o efeito de montagem entre a voz do dublador e a imagem do corpo do ator na tela. Isso ocorre pela habilidade humana de percepção, leitura e entendimento de gestos corporais, sobretudo os microgestos faciais ${ }^{6}$ : assim que se vê um ator na tela falando, mesmo que sem som, é possível, em algum grau, identificar os cinco elementos levantados. Logo, se a fala emitida pelo dublador não possuir esses elementos, não produzirá o efeito desejado. A seguir, os elementos citados serão detalhados:

1) Volume: é a intensidade do som da fala. É possível que se emita um som mais forte, ou mais fraco. O volume pode ser identificado no original a partir do som ou da imagem. Quando o ator original fala mais alto, ver-se-á a musculatura de seu rosto mais rígida, boca mais aberta etc. $O$ volume pode aumentar ou diminuir durante a execução da fala, o que deverá ser identificado, mapeado e duplicado a partir da imagem e também do som.

2) Tom: é a altura do som dentro da gama de frequências audíveis, podendo ser mais agudo ou grave. O conjunto melódico que compõe a fala pode ser dito em um tom agudo, intermediário ou grave. O esforço físico gerado para atingir determinados tons altera a musculatura facial, tornando-se visível no rosto do ator. Contudo, a maneira mais eficaz de perceber o tom é através do próprio som original. A execução do tom mais agudo ou grave não depende do volume, ou seja, pode-se emitir um tom mais grave com um volume mais alto, ou um tom mais agudo com um volume também mais alto e vice-versa;

3) Intenção: a intenção demonstra o objetivo e a emoção do personagem ao emitir a fala (sarcasmo, ironia, alegria, tristeza, raiva...). A intenção pode se apresentar isoladamente ou em conjuntos sobrepostos, e pode ser modificada durante a fala de maneira suave ou abrupta. A maneira mais eficiente de identificar a intenção ou conjunto de intenções e suas batidas (pontos que demarcam a alteração de uma intenção a outra) é através da observação atenta da imagem do corpo do ator na tela, sobretudo do rosto. O conjunto muscular do ator se modifica junto com a mudança de intenção que será apresentada no som emitido pelo ator. É importante também entender o contexto em que se encontra o personagem e sua trajetória; assim será possível entender suas motivações e objetivos. É difícil identificar a intenção pelo som emitido pelo ator, uma vez que na fala é na prosódia, sobretudo na musicalidade, que a intenção se apresenta, e a musicalidade se difere 
radicalmente em idiomas diferentes, confundindo ou tornando impossível a identificação da intenção apenas através do som;

4) Intensidade da intenção: é a intensidade das intenções presentes na fala, podendo ser mais intensa ou menos intensa. A intensidade não necessariamente modifica o tom ou o volume da fala; é possível que se aumente a intensidade sem que se modifique o volume e/ou o tom, ou que a dinâmica entre esses elementos seja contrária (aumentando a intensidade e diminuindo o tom e o volume, por exemplo; ou diminuindo a intensidade, aumentando o tom e diminuindo o volume - pode ser qualquer combinação). A intensidade fica clara no rosto do ator, que tensiona mais ou menos determinados músculos corporais, especialmente os faciais, modificando os microgestos e a leitura que se faz deles. Normalmente quando a intensidade aumenta as consoantes são mais valorizadas, devido ao aumento da tensão muscular do rosto e consequentemente do aparelho bucolingual, ou a pressão do fluxo de ar se intensifica;

5) Tempo-ritmo: na obra de Stanislavski, o conceito de tempo-ritmo pode gerar múltiplos entendimentos. Por um lado, relaciona-se a diversos aspectos internos e externos que afetam a emoção e seu ritmo mas também pode ser entendido como o estudo do ritmo métrico da fala. É um item complexo dentro do sistema de preparação do ator e construção do personagem desenvolvido por Stanislavski. Embora pareça óbvio utilizar o recorte do conceito de tempo-ritmo para o entendimento da métrica rítmica, uma vez que o sincronismo exige um ritmo de encaixe para a sincronização labial, este artigo abordará o conceito de tempo-ritmo como o movimento interno do personagem que é influenciado pelos elementos presentes em seu entorno, o estado de espírito dele. Stanislavski, neste sentido, define que

Em resumo: o tempo-ritmo contém não apenas as qualidades externas, que influenciam diretamente sobre nossa natureza, mas também o conteúdo interior que nutre o sentimento. Desta forma o tempo-ritmo se conserva em nossa memória, e é usado para a finalidade criadora (STANISLAVSKI, 1997a: 143, tradução nossa)

É possível que um som seja emitido sem que sejam alterados os elementos anteriores. Mas, ao modificar o tempo-ritmo, modifica-se também a prosódia. Por exemplo, mesmo que não sejam alterados os elementos anteriores, a prosódia sofre alterações se a fala for dita com o personagem apertado para ir ao banheiro, ou subindo uma montanha, ou em um velório, ou em um jantar romântico, e dependendo de com quem ele está interagindo. Essas circunstâncias externas alteram o estado de espírito interno do personagem, a maneira com que a imagem interna do dublador se estrutura, modificando a prosódia de sua fala, sua maneira de dialogar. Ele pode ser entendido pelo contexto ambiental do personagem e é preciso tentar se aproximar do temporitmo original. O tempo-ritmo é uma parte estruturante da composição da imagem endógena (que se contamina pelo ambiente) e se reconstruirá internamente no dublador; não é possível observar e determinar formalmente a complexidade do tempo-ritmo na obra original, é uma imagem que se inicia a partir de elementos externos presentes na cena, alimenta os processos imagéticos endógenos e contamina aspectos na forma final. É possível, no entanto, mapear os elementos que influenciaram o tempo-ritmo do personagem na tela pelo conjunto presente no entorno dele e o ambiente em que ele se encontra, que contamina o processo de desenvolvimento das imagens endógenas do intérprete original. 
É importante que o dublador tenha a capacidade de localizar, compreender, diferenciar e duplicar esses elementos exatamente como são apresentados no original. Eles se apresentam conjuntamente, no entanto suas dinâmicas são individuais: o volume pode aumentar enquanto o tom abaixa e a intenção se intensifica em tempo-ritmos diferentes, com intenções sobrepostas; eles podem se contaminar e se modificar em grupo ou se apresentar de maneiras isoladas e independentes. Portanto, o trabalho do dublador parte da observação atenta do audiovisual original para que, em seguida, seja feita sua duplicação fiel. É possível montar uma partitura dos elementos apresentados, com suas dinâmicas internas; contudo é interessante que o treinamento do dublador o leve a fazer a leitura e execução das dinâmicas desses elementos de maneira rápida, para que se abra tempo, durante o processo, de desenvolver suas imagens endógenas - o que será abordado posteriormente neste artigo - e, portanto, deve treinar a leitura e prática desses elementos específicos, individualizando-os e agrupando-os.

Esses elementos também precisam ser executados dentro de uma métrica rítmica na qual a tradução adequada das palavras contribuirá para o melhor encaixe no lipsync da imagem na tela, além da necessidade de as pausas serem dadas nos momentos corretos pelo dublador. A respiração e os sons de reação (interjeições sonoras emitidas pela boca, como choro, riso, grito etc.) também são importantes e devem ter a mesma relevância que as palavras, possuindo também todos os elementos detalhados anteriormente. Muitas vezes a respiração possui carga e importância de preparação para as palavras que serão ditas a seguir, tensionando ou aliviando a cena para o próximo diálogo; assim, é preciso utilizar esses elementos sonoros para tanto, dando-lhes o devido valor na composição da interpretação e na reprodução fiel do modo como foi feito pelo ator na tela.

Outro item que aparece no conteúdo original, mas não deve ser duplicado, é a musicalidade da fala feita pelo ator na obra original. Essa deve ser emitida pelo dublador de acordo com a musicalidade de seu próprio idioma e deve fluir da maneira mais natural possível. Toda língua possui um grupo de musicalidade distinta (que também varia de acordo com a região em que é falada), assim como cada pessoa também desenvolve uma musicalidade específica dentro do espectro de musicalidade de seu idioma. Cada dublador pode oferecer uma musicalidade diferente para o mesmo trecho sem que o sentido seja alterado; é preciso que o diretor de dublagem fique atento ao sentido dado por cada musicalidade, para que o regime de sentidos da obra se mantenha - mas, ao corrigir a musicalidade do dublador, também é preciso evitar que a referência que o diretor exige não engesse o processo de construção do ator, que pode passar a reproduzir a musicalidade pedida pelo diretor apenas pelos aspectos formais, obliterando o processo imaginativo e sensorial; o papel do diretor é conduzir o ator a criar suas próprias imagens endógenas que confiram o mesmo sentido à obra, e não robotizar o ator. Esse é o ponto de maior liberdade para a execução do dublador e onde comparecerá a emoção do personagem, é o ponto onde ele manterá o personagem preenchido, vivo e autêntico; é na musicalidade da fala que transbordarão as imagens endógenas do dublador (uma vez que os outros elementos descritos anteriormente são formalmente delimitados), frutos da imaginação dele.

\section{Iconofagia e eco}

As imagens presentes no audiovisual original, com todos os itens formais descritos anteriormente, se apresentam em um turbilhão: são muitos elementos e informações simultâneas para que o dublador processe, tente mapear e reproduzir. O perigo é que no excesso de zelo pela reprodução das características formais e estéticas, esqueça-se do trabalho imaginativo. 
O excesso dessas imagens exógenas e a falta de tempo para seu processamento pelo corpo do dublador propicia um movimento descrito por Baitello (2014), em sua teoria da imagem, como antropofagia impura, que é quando imagens engolem corpos: se o corpo não é capaz de engolir, contemplar e processar as imagens, elas engolem o corpo, utilizando-o para suas reproduções em eco, que permitem suas sobrevivências de maneira idêntica, no entanto esvaziadas. Dessa forma, as imagens garantem suas sobrevivências através da reprodutibilidade. Quando o corpo não é capaz de criar suas imagens endógenas para que possa entender as imagens exógenas a partir de suas imagens internas, as imagens exógenas invadem e engolem o corpo, e o utilizam para se reproduzir. Baitello define esse movimento de alimentação por espelhamento que culmina em eco:

O mundo das imagens exógenas só sobrevive e se mantém se for alimentado por espelhamento. E alimentar pelo espelhamento é alimentar com imagens idênticas ou similares. [...] Uma vez que já se descartaram as possibilidades construtivas de um novo oikos, só os ecos conferem legitimidade às imagens que nos são impostas invasivamente. (BAITELLO, 2014: 77)

Assim, se as imagens dos produtos audiovisuais originais não forem processadas pelo dublador, elas passam a engoli-lo, e como subproduto desse engolimento surge o eco.

No mito de Narciso, Eco era a ninfa que por maldição de sua mãe só conseguia repetir o final das frases que ouvia. Por esse motivo não foi correspondida em seu amor a Narciso, e se isolou transformando-se em um rochedo que continuou a repetir os finais dos sons a sua volta. As demais ninfas pedem vingança à deusa Nêmesis, que condena Narciso a um amor impossível, que se torna ele mesmo em seu reflexo. Ao ver seu reflexo nas águas, Narciso fica apaixonado pela sua excessiva beleza e é engolido pelas águas, se transformando na flor de Narciso. Narciso vem do grego, nárke, e significa entorpecimento, que tem raiz no indoeuropeu (s)nerg, que significa debilitar, enfraquecer, morrer (BRANDÃO, 1987: 173-190).

Negando a ninfa Eco por ser desinteressante ao apenas conseguir reproduzir os últimos sons que ouvia, Narciso entrega-se a seu destino: ser engolido por seu reflexo, pela atração por sua excessiva beleza estética. De certa forma, Narciso se apaixona por seu próprio eco imagético e, em seu torpor pelo excessivamente estetizante de sua imagem, tem sua morte.

O desafio do dublador é não sucumbir ao eco ao se confrontar com os aspectos estetizantes da imagem referente. Não se tornar rochedo imóvel como a ninfa Eco, tampouco ser engolido pelas imagens como Narciso. Não ser narcotizado, entorpecido, sedado pelas imagens.

Quando o dublador não é capaz de se alimentar dessas imagens, elas alimentam-se dele, e o dublador passa a agir de acordo com a programação dessas imagens, que fazem com que o intérprete, que se tornou agora imagem da imagem que o engoliu, passe a reproduzir essas imagens em eco: imagens destituídas de interior, externamente parecidas com suas imagens referentes, mas esvaziadas de emoções. Nesse momento temos o movimento iconofágico completo: o outrora corpo, agora imagem da imagem que o engoliu, é continuamente engolido pelas imagens exógenas e, quando imagem engole imagem no corpo, ocorre a iconofagia.

O eco engole seu referente real e se apresenta como ele próprio, embora esvaziado. $\mathrm{O}$ eco é oco. $\mathrm{O}$ corpo, agora imagem, anestesiado pelas imagens que o engolem, já não tem mais a capacidade de se emocionar e apenas reproduz a carcaça estético-formal de seus referentes sonoros, de maneira automatizada e 
programada. O corpo do dublador, nesse momento, pode-se dizer, foi possuído pelas imagens audiovisuais que deveriam ser referência para seu processo de criação e passaram a programar o dublador a ecoá-las incessantemente, sem processamento, sem contemplação, esvaziando-as de sentido, de emoções, em uma programação hermética.

Nesse ponto, o dublador perde a capacidade de não duplicar a musicalidade do produto original, e sua prosódia não confere emoção, acabando por se robotizar. Aqui, o artista dissolveu-se; não há espaço de pensamento, não há imaginação. Inúmeras dublagens padecem de eco. Aparentemente - esteticamente e formalmente - preenchem e substituem o idioma original; no entanto, não emocionam, estão esvaziadas. No dublador não há movimento interno, e o espaço de desenvolvimento de suas imagens endógenas foi consumido pelo engolimento das imagens exógenas.

A preocupação pela reprodução excessivamente estetizante leva ao eco, pois não se atenta com o processamento e a repetição, mas com a réplica fiel e meramente estética da composição que culmina no esvaziamento e apagamento das raízes que constituíram a imagem referente, no apagamento da força imaginativa.

Para não se deixar ser engolido pelas imagens é preciso ter entendimento dos processos iconofágicos: só é possível não ser engolido sabendo que existe a possibilidade de sê-lo, sabendo das pretensões das imagens e de seus movimentos fágicos.

\section{A repetição}

O trabalho do dublador é reproduzir. Ele precisa, portanto, se alimentar das imagens oferecidas e utilizá-las como insumo para a produção de suas próprias imagens; precisa engolir as imagens entendendo-as, processando-as e sendo afetado por elas, não se permitindo ser sedado por elas, entrando em uma passividade de consumo de imagens que o leva a ser consumido por elas.

Quando corpos se alimentam de imagens ocorre um movimento de iconofagia impura. Corpos que processam as imagens e se alimentam delas não se deixam ser alimentados por elas: não se transformam em imagens, não se deixam ser utilizados pelas imagens. $O$ dublador precisa reproduzir a forma estética, mas deve fazer em um movimento contrário ao eco, de não apagamento de suas raízes, de reconstrução de seu sentido interno, e isso só é possível com o uso da repetição, no sentido empregado por Kierkegaard.

Sören Kierkegaard, filósofo dinamarquês, faz um elogio à repetição. Para ele, repetir é um ato de coragem, é não apagar a recordação, mas sim revivê-la, é não promover o efêmero que, segundo ele, entretém e amolece a alma. É rumar à frente, mas sem se esquecer do que veio antes. "Repetição e recordação são o mesmo movimento, apenas em direção oposta; pois aquilo que se recorda, foi, repete-se para trás; enquanto a repetição propriamente dita é recordada para diante" (KIERKEGAARD, 2009: 32). Repetir é o movimento de trazer a memória para a frente; um resgate do passado, da genealogia; é entender os processos e reconstruí-los; é lutar contra o apagamento, a falta de sentido e o vazio. Para Kierkegaard,

A dialética da repetição é fácil; porque aquilo que se repete foi, caso contrário não podia repetir-se, mas precisamente o fato de ter sido faz com que a repetição seja algo de novo. Quando os gregos diziam que todo o conhecer é recordar, diziam que toda a existência que existiu passa agora a existir. Se se 
não dispõe da categoria da repetição, a vida dissolve-se toda ela num ruído vazio e sem sentido. (KIERKEGAARD, 2009: 51-52)

Enquanto o eco é a reprodução da forma externa com o sentido esvaziado, a repetição é a reprodução a partir do interior, de suas forças motivadoras, da rememoração de seu sentido para a frente. A motivação do eco é o vazio, a da repetição é a reconstrução da memória.

O interior, para o dublador, é a imaginação. Seu trabalho é a tentativa de repetição das imagens internas que estruturam e dão vida à interpretação do ator presente na tela, e é preciso ter coragem para repeti-las; é repetir o interior das imagens que se colocam à sua frente usando de seu próprio interior; é uma tentativa de captar o que há de profundo nas imagens e reconstruir esses elementos movimentando o que há de profundo em sua imaginação; é deixar-se ser afetado por imagens e se emocionar, para que possa construir imagens sonoras que sejam cheias de sentimentos. Ser afetado para sentir; sentir para afetar.

Sentimento, do latim sentio (perceber pelos sentidos), tem sua raiz no indoeuropeu sent-, que significa tomar uma direção. Afeto tem origem na palavra latina affecto, e significa a intenção de alcançar algo, dedicar-se a algo; já sua raiz indo-europeia dhe-, significa consertar, modificar, reconstruir (ARTIGUES; ROBERTS, 2019). É possível relacionar as duas palavras em suas intenções motivadoras: ter sentimento para afetar, em suas raízes etimológicas pode significar tomar uma direção para consertar/reconstruir/modificar. As imagens em repetição, a partir de suas reconstruções, podem emocionar, levar a sentimentos para afetar, desembocando no conserto, na modificação das sensorialidades de quem as recebe, movendo e de alguma maneira até transformando esse sujeito, devolvendo-lhes suas raízes, suas profundezas, seu pertencer-se a si mesmo e a sua genealogia. Esse é o poder da imaginação e suas raízes profundas, que deve ser o objetivo do artista: ser uma ponte ao sensorial, levar a reconexões.

\section{Considerações finais}

No processo de reprodução do conteúdo original, o dublador por um lado não pode escapar da forma estética do conteúdo a ser reproduzido, e por outro ele também não pode deixar esvaziar seu movimento imaginativo de produção de imagens endógenas que transbordarão em suas palavras e formarão as imagens sonoras, as quais se sincronizarão com a imagem já existente, procurando manter seu conteúdo simbólico e cheio de emoções e sentimentos, repleto de afetos que levem a movimentos, a sensorialidades e a reconexões.

A execução da forma estética, com a utilização dos itens formais mapeados pelo presente artigo, embora imprescindível, não deve ser encarada como a totalidade do processo. Como é de ordem mecânica, deve ser treinada para que flua sem que se perca tempo com esses itens durante o processo, para que ocorra de maneira natural. Deve-se priorizar não permitir ser engolido pelas imagens que se colocam como referência, utilizando-as, do contrário, como alimento para um processamento sensorial de imagens que ajude a reconstruir imagens sonoras preenchidas e vivas, repletas de simbólico e transbordantes de imaginação. Assim, o dublador não fará eco, mas repetições.

O processamento das imagens pelo corpo não deve ser da ordem racional e lógica, mas um pensar-imagem. É um pensar sem pensar, um pensar com o corpo e suas múltiplas sensorialidades. É deixar-se levar pelas imagens aos seus 
estímulos mais profundos, sem ser engolido e narcotizado por elas - e, sobretudo, sem apagar suas raízes.

No fim de A Preparação do Ator, Stanislavski diz que desenvolveu seu método com diversos aspectos formais - para ser usado como um treinamento que permitiria ao ator não racionalizar na hora de interpretar o personagem, entregando-o às ações de seu subconsciente. Isso aconteceria porque o ator, após o treinamento, não se preocuparia mais com os aspectos formais, eles fluiriam naturalmente, abrindo espaço para a ação do que ele chama de subconsciente. Ele compara os itens de seu treinamento com a gramática, e o estado em que o ator deveria estar em cena com a poesia. Diz que "é justo dizer que essa técnica tem com a natureza criadora subconsciente a mesma relação da gramática com a poesia. É triste quando considerações gramaticais avassalam o poético" (STANISLAVSKI, 1996: 296). O mesmo vale para a dublagem: não se pode deixar que a gramática avassale o poético e que os elementos estético-formais eliminem a imaginação.

\section{Referências}

ARTIGUES, B. P.; ROBERTS, E. A. Diccionario Etimológico Indoeuropeo de la Lengua Española. Madrid: Alianza Editorial, 2019.

BAITELLO, Norval. A era da iconofagia. São Paulo: Paulus, 2014.

BELTING, H. Antropologia da imagem: para uma ciência da imagem. Lisboa: KKYM + EAUM, 2014.

BRANDÃO, Junito de Souza. Mitologia grega: vol. II. Petrópolis: Vozes, 1987.

EIBL-EIBESFELDT, Irenäus. El hombre preprogramado. Madrid: Alianza, 1983.

FLUSSER, V. A escrita: há futuro para a escrita?. São Paulo: Annablume, 2010.

FLUSSER, V. O mundo codificado. São Paulo: Cosac Naify, 2013.

HEISE, C. G. Persönliche Erinnerungen an Aby Warburg. Wiesbaden: Harassowitz Verlag, 2005.

KIERKEGAARD, Sören. A Repetição. Lisboa: Relógio D’Água, 2009.

STANISLAVSKI, C. A preparação do ator. Rio de Janeiro: Civilização Brasileira, 1996.

STANISLAVSKI, C. El trabajo del actor sobre si mismo em el proceso creador de la encarnación. Argentina: Quetzal, 1997a.

STANISLAVSKI, C. Manual do ator. São Paulo: Martins Fontes, 1997b.

ZARATIN, T. N. Comunicação verbal: educação vocal: o teatro: fonte e apoio. São Paulo: Paulus, 2010. 